\title{
MAGMATIC EMPLACEMENT OF NORTHWESTERN GREECE OPHIOLITES
}

\author{
J. H. BRUNN, I. ARGYRIADIS, J. BRAUD
}

\begin{abstract}
New field observations reinforce the interpretation that was admitted from 1956 to 1970 according to which the ophiolites of Northwestern Greece were generated and emplaced as a massive submarine flow of mantelic magma which had risen through the opening of an orogenic rift. As it opened, the still narrow rift left out submarin tuffs and lavas (pillows) which have been found in different places under the basal peridotites of ophiolitic suits.

\section{RESUME}

Des nouvelles observations de terrain confirment et renforcent l'interprétation qui avait été généralement acceptée entre 1956 et 1970 selon laquelle les ophiolites du NW de la Grèce ont été engendrées et mises en place sous la forme d'une émission massive et sous-marine de magma mantélique monté à la faveur de l'ouverture d'un rift orogénique (différent des rifts océaniques). A son début, cette ouverture encore modeste a projeté dans la mer des matériaux de volcanisme explosif et des laves que l'on retrouve sous la forme de tuffs et de pillow-lavas en plusieurs endroits sous les péridotites de base des séries ophiolitiques. La haute température de cette mise en place est prouvée par le métamorphisme de contact atteignant le faciès amphibolite.
\end{abstract}

\section{INTRODUCTION}

The ophiolites of NW Greece provide a lot of varied and constraining informations concerning their generation and mode of emplacement. Following two field trips that we made during the summers of 2000 and 2001 we found new confirmation of the interpretation proposed by one of us (BRUNN $1940 \mathrm{a} \& \mathrm{~b}, 1950,1956,1960$ ) and generaly accepted until 1970, (cf. biblio. AUBOUIN, MAXWELL, MERCIER, MOORES) according to which theese ophiolites were generated and emplaced as a massive submarine flow of mantelic magma that had reached the sea floor owing to the opening of an orogenic rift (more sudden, wider and shorter in time than oceanic rifts) that occured during the middle Lias.

Following the plate tectonic or «global» theory, the hypothesis of a rigid «plate tectonic emplacement of upper mantel peridotites along continental edges» was introduced by R.G.Coleman (1971) under the name of «obduction». It specified that the «obducted plate» was a «cold slab» of oceanic crust and mantel. In support of this, he quoted the old idea that ultrabasic rocks do not induce thermic matamorphism at their contact. This was proved wrong for, from 1973 onwards, thermal metamorphism reaching the amphibolite facies was found under basal peridotites of ophiolites in many places. Then, other models were put forward keeping the word «obduction» but admitting that the base of the obducted slabs were at temperatures as high a $120 \mathrm{O}^{\circ} \mathrm{C}$ and pressures as low as $2 \mathrm{~Kb}$ (DEWEY and SHACKELTON 1984).

Yet all these models inspired by «global tectonics» imply a mechanical contact of abnormal superposition between ophiolitic masses and their substratum. This does not seem to correspond to the facts we observed in the field. We essentially focused our attention on the visible base of the ophiolites and the nature of their contact with their basement. 


\section{A. CROSS SECTION OF THE VALLEY OF THE ALIAKMON RIVER AT THE SOUTHERN END OF THE VOURINOS-FLAMBOURON PERIDOTITIC RANGE.}

Owing to a large transverse accident, the Aliakmon river coming from the NW turns here towards the ENE. It is bordered to the $\mathrm{S}$ by the northern slopes of the Mount Vounassa which are covered by triassic limestones dipping $60^{\circ} \mathrm{NNW}$ while the pre-triasic metamorphic formations outcrop on the southern flank of the mountain. The northern side of the valley initially steep becomes milder when it reaches the peridotites of Mount Flambouron.

The cross sections are south-north. The lower part of the cross section is observable on the western end of the Mount Vounassa along the road from Dheskati to Peliouria. Above the metamorphic formations are found discontinuous patches of red conglomerats similar to those that were ascribed to the Permian by Kossmat (1924) in southern Yougoslavia and then comprises, upwards, quarzites, thin plated nodular,gray, yellow and violet limestones, a facies that recalls the Anisian of the eastern Alpes, then, alternating quartzites and gray thin platted limestones at last violet, brown or green cherts.

The rest of the section is observable slightly to the $\mathrm{E}$ on the southern slope of the Aliakmon valley, half way between the Zabordas Monastery to the E and that of Panaghia-Tourniki to the W. It shows from S to N (fig. 1):

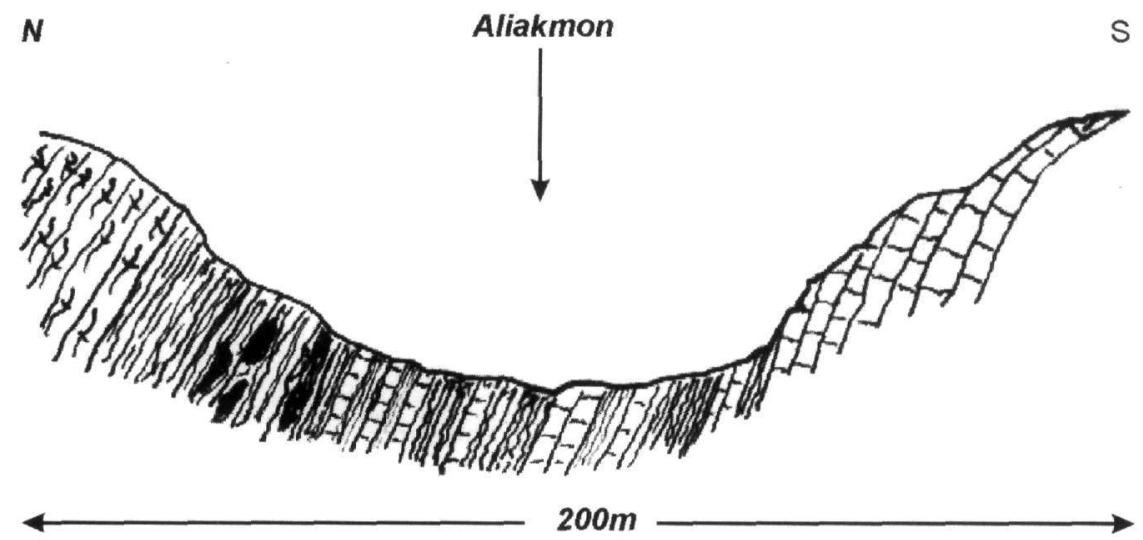

Figure 1. Cross section, Aliakmon valley

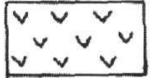

1

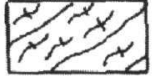

2

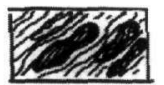

3

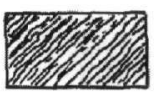

4

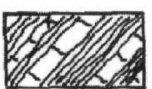

5

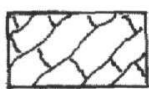

6

1 : serpentinized peridotites 2 : amphibolites $3:$ tuffs and pillow lavas 4 : calcshists, radiolarian cherts and tuffs

5 : thin bedded marbles, calcschists and tuffaceous cherts 6 : marbles (triassic)

- Thick-bedded Vounassa marmorian limestones with dark colored weathering. The top of the formation has been dated as Norian by Conodonta (Mavridis 1980) while similar limestones above Siatista (35 km. north ) were dated in there middle part as Ladinian by Diplopora ( Teutloporella sp.,BRUNN 1956)

- Marmorian limestones in thinner beds (about $10 \mathrm{~cm}$.) with gray green intercalations of tuffs

- Few meters of marmorian limestones

- Elliptic bodies of very dark green to black vitreous lavas intercalated in marmorian limestones

- Metamorphic calcschists intercalated with volcanic tuffs, both over 20 m.thick

- Tuffs and pillow-lavas over a few tens of meters thick, passing progressively to:

- Layered amphibolites forming the cliff on the left bank. The metamophism of these amphibolites was dated by Spray and Roddick (1980) to be - 170, $-180 \mathrm{MA}$ through ${ }^{40} \mathrm{Ar} /{ }^{39} \mathrm{Ar}$.

- The serpentinised peridotites of the Flambouron.

This succession is similar to that described by BRUNN (1956) \& PICHON (1985). They are undeniably 
normal and show no trace of thrusting. They show, towards the top, the gradual invasion of the sedimentary environment by volcanic material and a certain deepening of the sea (thinner and siliceous beds). Then volcanic environment prevales, carbonate deposites disapear and everything indicates the impending major magmatic event. This announced event is the arrival of the ophiolitic mass. Its high temperature is prooved by the presence of amphibolites, its magmatic condition by the absence of thrusting markers.

\section{B. THE NORTHERN VOURINOS CONCEPTION}

We cannot leave this area without recalling the superb cross-section of the North Vourinos, south of Paleocastro (fig. 2). Looking south, it shows on left (east) to right (west):

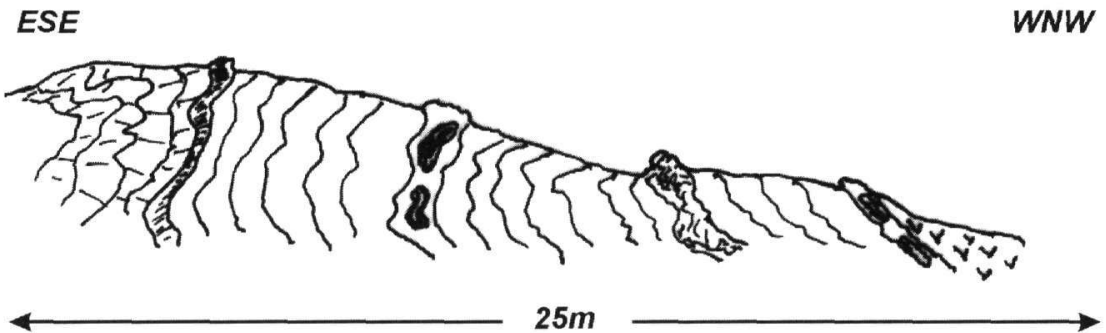

Figure 2. Cross section by Ag. Dimitrios

- the triassic limestones subvertical, dipping west

- the schists, former tuffites corresponding to a gorge

- the peridotites of the Vourinos (1866 m); faintly layered and vertical:serpentinized dunite, harzburgite with chromite deposits, Iherzolite, etc., pyroxenite

- In the east-west valley of the Aliakmon, layered gabbros, first with dark olivine and instatite beds and bitownite rich layers, then augite rich and endesine rich layers. The layering is subvertical, parallel to that of the triassic limestones. This conformity prooves that the magma settled on the horizonntal sea floor and that the differenciation and layering occured within the magma chamber

- Non layered gabbro-diorites and quartz-diorites showing that the top of the chamber was enriched in water; under the dolerites, angular blocs of the latter have fallen into the water-rich magma, forming a «magmatic breccia» (Brunn, 1956, Plate XVII, fig. 3)

- Dolerites and basalt under the villages of Asprokambo and Langadakia

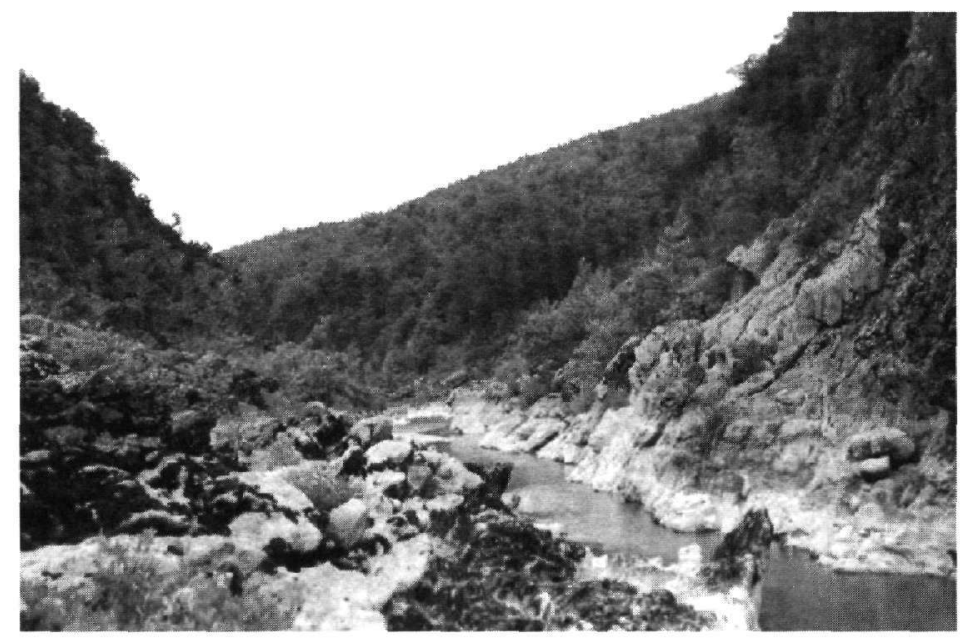

Figure 3. The Aliakmon valley cross section

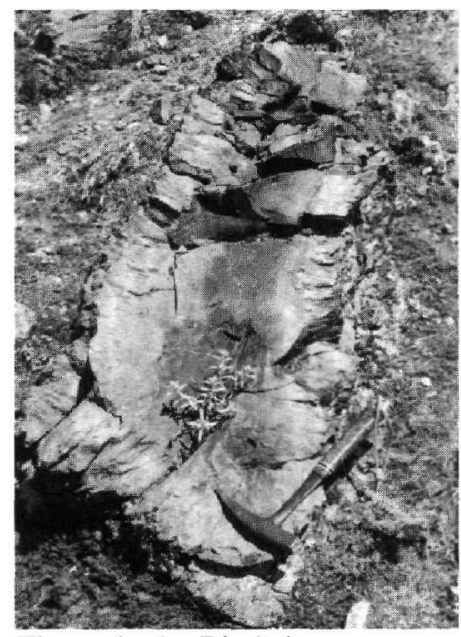

Figure 4. Ag. Dimitrios cross section : pillow lava 
- Thin cherts and pelagic limestones of jurassic age (Calpionella)

- Transgressive, slightly discomformable Upper cretaceous micrites.

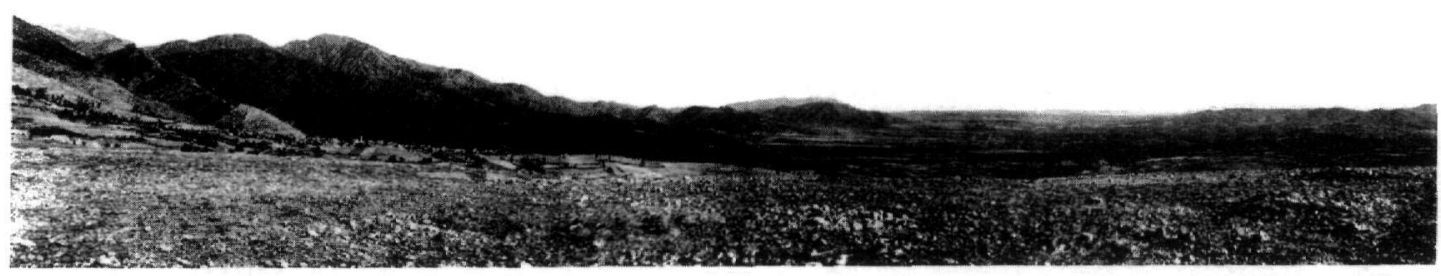

Figure 5. Panorama of the Vourinos and Krapa hills (view towards the South).

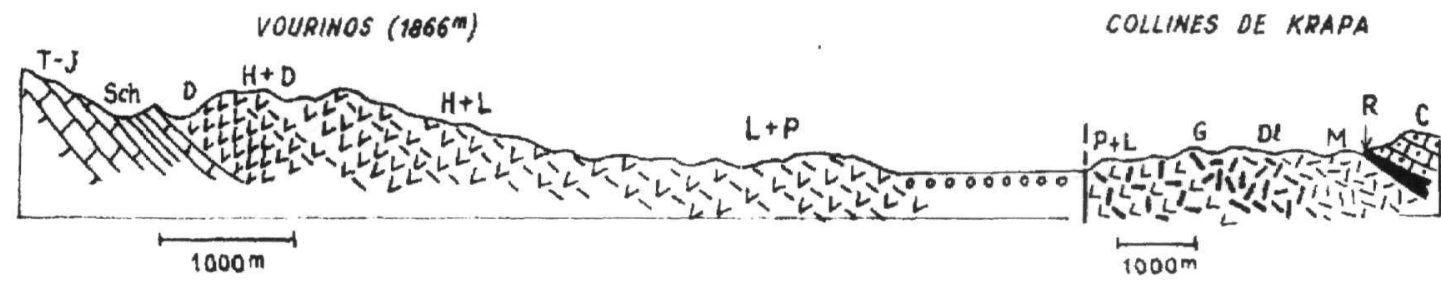

Figure 6. Explanatory profile of the view (scale distorted by perspective).

$\boldsymbol{T}-\boldsymbol{J}$ : limestones (Trias, Jurassic) ; Sch : intercalations of schists and cherts in the top of limestones

$\boldsymbol{D}$ : dunites ; $\boldsymbol{H}$ : harzburgites $; \boldsymbol{L}$ : lherzolites ; $\boldsymbol{P}$ : pyroxenites ; $\boldsymbol{G}:$ gabbros $; \boldsymbol{D l}:$ dolerites $; \boldsymbol{M}:$ microlitic rocks ;

$\boldsymbol{R}$ : radiolarites ; $\boldsymbol{C}$ : cretaceous limestones.

\section{CROSS SECTION OF AG. DIMITRIOS.}

Of course our next aim was to extend the upper observations and verify if these observable facts could be seen elsewhere. Far more to the E, on the western side of the Mount Vermion, a transverse sinkline above the village of Ag. Dimitrios exposes the base of the serpentinous ophiolites in contact with the marble of their bedrocks. The cross-section is made over the village, on the road leading to the monastery of Ag. Ioannis Vazelonos, 1000m high. This cross-section is oriented E-W and the layers are exposed with a nearly vertical dip from $\mathrm{E}$ to $\mathrm{W}$, that is to say upwards and we can see:

- Fine layered marbles

- Schisteous tuffs

- Pillows lavas with magnificent «pillows» (about $1,5 \mathrm{~m}$ thick)

- Schisteous tuffs

- New flow of pillow-lavas

- Serpentineous tuffs

- At last, the serpentineous ophiolitic mass.

Here also the base contact of the ophiolites is normal, stratigraphic and their arrival is announced by a striking volcanic environment. The ophiolitic suite is much thinner than in the Vourinos.

\section{CROSS-SECTION OF MILIA}

The ophiolites forming the summits of the northern Pindos are thrust SW over the eocene flysch of the Pindos zone which is itself thrust over the eo-oligocene flysch of the Tymphe-Gavrovo zone (BRUNN 1956). Within the nappe the Pindos flysch appears under the ophiolites in techtonic windows. The remarquable thing is 
that the ophiolites have been thrust with their normal base at least pro parte as we have noticed it in our last field observation.

The village of Milia (ENE of Metsovon) lies on a half-window of Flysch appearing from under the thrust ophiolites. The flysch-ophiolites contact is borded from place to place by huge «thrust slices» of limestones, the most important of which is the so-called «Petra tou Lykou» as big as a great building in which one of us (BRUNN 1956) had found Halobia radiata GEMM. from the upper Triassic period (determination from C.RENZ). These «thrust slices» were said to have been tectonically dragged, in a certain desorder, by the ophiolitic overthrust. But, this time, as we were particularly focused on these sites, we noticed that they form in fact a coherent zone, stratigraphically located along the old road to Metsovon, from Milia to Politses. Some local cross-sections, nearly identical, confirm by their systematic disposition this point of view. The best and clearest one is found south uphill to Milia at the dump of the village. In contact with striped amphibolites forming the base of the ophiolitic mass, we can see series of red schists and radiolarian cherts with intercalations of typical well preserved «pillow-lavas» with strips (metric) of pink and white lithographic limestones full of «filaments», probably sections of very fine tests of Halobia or Daonella from the Triassic period.

\section{E. CONCLUSIONS}

A detailed and longstanding cartographic work should be started to understand and describe the disposition of this zone. But we can already formulate some conclusions which support a more synthetic view of the structure of the Hellenides and more generally speaking, of the Alpino-Mediterranean Range which is not that of «classic» models of the so-called «global tectonic».

- The superposition of the NW Greek ophiolites on their immediate substratum is normal and not tectonic.

- This substratum is a part of the thrust nappe of the Pindos.

- The ophiolites which appear to the NE of the Meso-hellenic trench are part of the normal mesozooc cover of the inframesozoic and usualy metamorphic formations of the «Pelagonian basement» (sensu F. Kossmat,1924).

- Apart from the Vourinos, other ophiolitic outcrops can be found in the Pelagonian Zone (Monts Askion et Vermion). They ly also on Triassic limestones, which are sometimes metamorphic, often through a layer of schists, former tuffites and lavas ; they are less important and thinner than those of the Vourinos, partly owing to erosion, partly because they were initially less important and their differentiation less advanced : the bottom of the sea was probably uneven and not flat as are the abyssal oceanic plains.

Finally, these observated facts should lead to reconsider the hypothesis of a unique «Tethysian Ocean» the bottom of which would have been inserted by «obduction» in the alpino-mediterranean range : more probable, owing to the field observations we have made, is the opening, during or after the Triassic age, of several rift-like trenches through which flowded ultrabasic magmatic masses from which are issued the alpine ophiolites.

\section{REFERENCES}

ARGYRIADIS I. 1975. Mésogée permienne, chaîne hercynienne et cassure téthysienne. Bull. Soc. Géol. Fr., (7), p. 56-67.

ARGYRIADIS I. AND FOURQUIN CL. 1987. La structure du complexe de nappes rhodopien en Grèce : une fenêtre hellénique africaine sous les Balkans. C.R. Acad. Sci. Paris, t. 305, Série II, p. 727-732.

AUBOUIN J. 1965. Geosynclines, Elsevier ed., Amsterdam.

BORTOLOTTI V., DALPIAZ G.V. and PASSERINI P. 1969. Ricerchesulle ofioliti delle catene alpine 5. Nuove osservazioni sul massiccio del vourinos (Grecia). Bol. Soc. Geol. Ital. 88 (1969), p. 35 - 45, 5 fig.

BRAUD J. and BRUNN J.H. 1972. Présence de quartz-kératophyres et de brèches éruptives dans les roches vertes des unités almopiennes occidentales du Vermion (Grèce). C.R. somm. Soc.Géol. Fr., 1972, fasc. 1 (7/2) p. 29-30.

BRUNN J.H. 1940 a. Sur les roches basiques du Pinde et de la Macédoine occidentale, C.R. Ac. Sc. 210, p 109111.

BRUNN J.H. 1940 b. Conditions de gisement des roches basiques en Macédoine occidentale.C.R. Ac. Sc. 210, p 735-738. 
BRUNN J.H. 1952. Les éruptions ophiolitiques dans le NW de la Grèce et leurs rapports avec l'orogenèse. 19 ème congrès géol. Int.17, 19-27.

BRUNN J.H. 1956. Contribution à l'étude géologique du Pinde septentrional et de la Macédoine occidentale. Ann. Géol. Pays Hellen. vol. 7, 410p.

BRUNN J.H. 1960. Mise en place et différenciation de l'association pluto-volcanique du cortège ophiolitique. Rev. Géogr. phys. Géol. dyn., Sér. 2,3 : 115-132.

COLEMAN R.G. 1971. Plate tectonic emplacement of upper mantle peridotites along continental edges. J. Geophys. Res. 76:1212-1222.

DEWEY J.F. and SHACKLETON R.M. 1984. A model for the evolution of the Grampian tract in the early Caledonides and Appalachians. Nature, 312:115-121.

KOBER L. 1915. Alpen und Dinariden. Geol. Rdsch. 5, 175-204, Leipzig 1915.

KOSSMAT F. 1924. Geologie der zentralen Balkanhalbinsel. Mit einer Uebersicht des dinarischen Gebirgsbaus. Die Kriegsschauplätze 1914-1918 geologisch dargestellt. Heft 12. Berlin, Borntraeger.

KOSMAT F. 1937. Der ophiolitische Magmagürtel in den Kettengebirgen des mediterranen Systems. Sitzung. Preuss. Akad. Wiss. 23, p. $308-325$.

MAVRIDIS A. 1980. A propos de l'âge de mise en place tectonique du cortège ophiolitique du Vourinos (Grèce), in : A. Panayiotou (Ed.) Intern. Ophiolite Symp. Cyprus 1979, p. 349-350.

MAXWELL J.C. and AZZAROLI A. 1962. Submarine extrusion of ultramafic magma (abstract). Geol. Soc. Amer. Spec. Paper $73:$ 203-204.

MERCIER J. 1968. Etude géologique des zones internes des Hellénides en Macédoine centrale (Grèce). Ann. Géol. Pays Helléniques. 20 : 596p.

MOORES E.M. 1969. Petrology and structure of the Vourinos ophiolite complex of Nothern Greece. Geol. oc. amer., Spec. Paper, 118, 74p.

RENZ C. Die Tektonik der griechischen Gebirge. Mém. Acad. Ath. 8, p. $1-171$.

SPRAY G. and RODDICK J.C. 1980. Petrology and ${ }^{40} \mathrm{Ar} /{ }^{39} \mathrm{Ar}$ geochronology of some Hellenic cub-ophiolitique metamorphic rocks. Contrib. Mineral. Petrol., 72:43-55. 